J. Appl. Glycosci., 51, 55-61 (2004)

(C) 2004 The Japanese Society of Applied Glycoscience

Award Address: Distinguished Young Scientist Award of the 2003's JSAG

\title{
Properties and Application of Enzymes for Bacterial Glycogen Biosynthesis and Degradation
}

\author{
(Received September 19, 2003) \\ Hiroki Takata* \\ Biochemical Research Laboratory, Ezaki Glico Co., Ltd. \\ (4-6-5, Utajima, Nishiyodogawa-ku, Osaka 555-8502, Japan)
}

\begin{abstract}
Structures and properties of enzymes for bacterial glycogen metabolism have been investigated. Branching enzyme (BE, EC 2.4.1.18), which is responsible for $\alpha-1,6$ glucosidic linkages of glycogen, was found to catalyze cyclization of amylose. It was suggested that the ratio of branching to cyclization reactions is dependent on the size and concentration of substrate. We also demonstrated that the thermostable $\mathrm{BE}$ from $\mathrm{Ba}$ cillus stearothermophilus efficiently catalyzes cyclization of $\mathbf{B}$ chains of amylopectin to produce highlybranched cyclic dextrin, Cluster Dextrin ${ }^{\mathrm{TM}}$. In spite of its high molecular weight and relatively long unit chains, Cluster Dextrin ${ }^{\mathrm{TM}}$ is highly soluble in water and shows characteristic properties for food and non-food applications. Moreover, glycogen-like polysaccharide with an extremely high molecular weight $(>\mathbf{1 0 , 0 0 0 , 0 0 0 )}$ could be synthesized by using $\alpha$-glucan phosphorylase with BE. Properties of other enzymes for glycogen metabolism are also described. Comparison of the primary structures of ADP-glucose pyrophosphorylases (AGPs) derived from genome projects and the experimental results using the enzyme from B. stearothermophilus suggest a remarkable variety of AGP.
\end{abstract}

Key words: branching enzyme, cyclization, dextrin, glycogen, ADP-glucose pyrophosphorylase

\section{細菌グリコーゲン合成・分解系酵素の性質と，そのデンプン加工 への利用に関する研究**}

\author{
高田洋樹* \\ 江崎グリコ株式会社生物化学研究所（555-8502 大阪市西淀川区歌島 4-6-5）
}

グリコーゲンは，動物，糸状菌類，酵母，細菌および始 原菌に広く分布する貯蔵多糖であり， $\alpha-1,4-$ グルコシド結

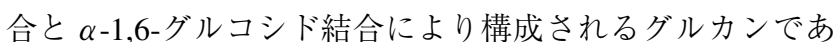
る。細菌グリコーゲンは，植物のデンプンと基本的に同じ 酵素セットによって Fig. 1 に示す経路により合成される.

一方，グリコーゲンの分解経路については，その詳細は未 解明であるが，加水分解酵素である $\alpha$-アミラーゼ，枝き り酵素， $\alpha$-グルコシダーゼなどと, 加リン酸分解酵素で ある $\alpha$-グルカンホスホリラーゼなどが関与すると考えら れる。

私たちは，新たなデンプン加工用酵素の開発という見地 から，これらの酵素について興味をもち，特にBacillus 属 細菌のグリコーゲン合成・分解系酵素に関する研究を行っ た。

本稿では主としてブランチングエンザイムの反応と利用 について述べる。また，他の酵素について得られたいくつ かの新しい知見についても簡単に触れる.

* Tel. +81-6-6477-8425, Fax. +81-6-6477-8362, E-mail: takatahiroki@glico.co.jp.

**平成 15 年度日本応用糖質科学会奨励賞受賞講演
1. ブランチングェンザイムとは

ブランチングエンザイム（系統名：1,4- $\alpha$-D-glucan：1,4$\alpha$-D-glucan 6- $\alpha$-D- (1,4- $\alpha$-D-glucano) -transferase, EC 2.4.1.18.

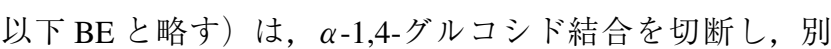
のグルコース残基の 6 位 $\mathrm{OH}$ 基に転移することにより， $\alpha-1,6$-結合を合成する。 $\mathrm{BE}$ は動物，植物，系状菌類，酵 母，および細菌に広く分布しており，グリコーゲンあるい はデンプンの分岐結合合成を触媒している。

1970 年代にBorovsky $ら^{1-4)}$ が，馬鈴薯 BE の反応につい て詳細に調べ，BE が分子間枝作り反応（Fig. 2 A）を触媒 することを証明した。一方，分子内枝作り反応（Fig. 2 B) が触媒されるかどうかは，不明と述べられている，BEは Glycoside Hydrolase Family 13 ( $\alpha$-アミラーゼファミリー) の一員とされ， $\alpha$-アミラーゼと基本的に同一のメカニズ ムにより，単一の活性中心において $\alpha-1,4-$ 結合切断と 6 位 $\mathrm{OH}$ 基への転移を触媒すると考えられている ${ }^{5-7)}$.

BE は, 応用面からは, デンプン構造改変用酵素として 注目されていた ${ }^{8)}$ が，実用には至っていなかった。

2. BE のアミロースへの作用

私たちは，耐熱性 $\mathrm{BE}$ 生産菌を自然界から検索し，Ba- 


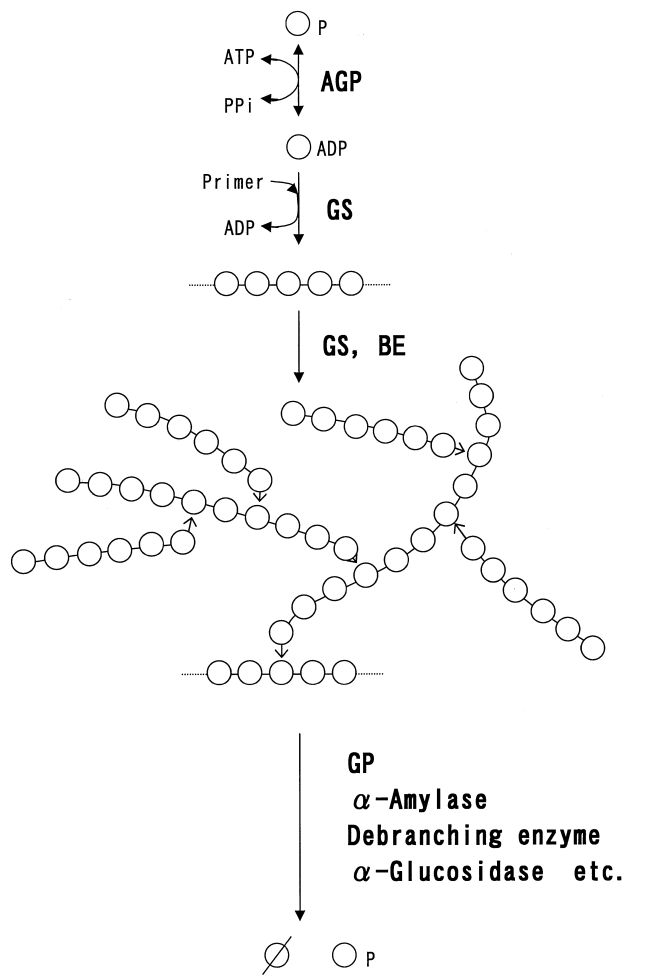

Fig. 1. Pathway for bacterial glycogen biosynthesis and degradation.

$\bigcirc$, glucosyl residue; $\varnothing$, glucose; $\downarrow, \alpha-1,6$ glucosidic linkage; 一, $\alpha-1,4$ glucosidic linkage; $\bigcirc \mathrm{P}, \alpha$-D-glucosyl 1-phosphate; $\bigcirc_{\mathrm{ADP}}$, ADP-glucose; AGP, ADP-glucose pyrophosphorylase; GS, glycogen synthase; BE, branching enzyme; GP, $\alpha$-glucan phosphorylase, PPi, pyrophosphate.

cillus stearothermophilus TRBE 14 株を選択した。本菌株よ り $\mathrm{BE}$ 構造遺伝子を単離し, 大腸菌を宿主とした遺伝子発 現系を構築し，酵素の諸性質を調べた ${ }^{6)}$.

得られた耐熱性 BE のアミロースへの作用を調べている とき，反応とともに基質分子量が低下していくことを見出 した . このとき還元力上昇は非常にわずかであり，加水 分解反応による低分子化ではないと考えた. 分子間枝作り 反応，または分子内枝作り反応では，分子の数が反応前後 で変わらないため, 平均分子量も反応前後で変化しない (Fig. 2 A，B)。一方，環状化反応（Fig. 2 C）を想定すれ ば，還元力上昇を伴わない低分子化を説明できる．環状構 造部分は，生産物をグルコアミラーゼ処理することによっ て単離することができた9)。得られたグルコアミラーゼ耐 性グルカンは， $\alpha$-アミラーゼを作用させることによって 容易に分解された。 また，イソアミラーゼとグルコアミ ラーゼを同時に作用させることによっても分解された。さ らに，質量分析を行ったところ，グルコアミラーゼ耐性成 分の分子量は, $162 n$ ( $n$ は重合度) であり, 還元末端を もたないことが確認された9).

$\mathrm{BE}$ による環状化反応は，非常に特殊な反応という印象 を受けるかもしれない. しかし, Fig. 2 B と C を見比べる と, 分子内枝作り反応と環状化反応は基本的に同じである ことがわかる。つまり， $\alpha-1,4$-結合を切断した後，切断位 置から還元末端側の残基に転移すれば，分子内枝作り反応 であり，逆に非還元末端側の残基に転移すれば，環状化反
A : Intermolecular branching reaction

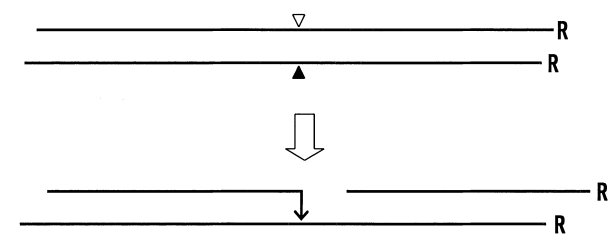

B : Intramolecular branching reaction

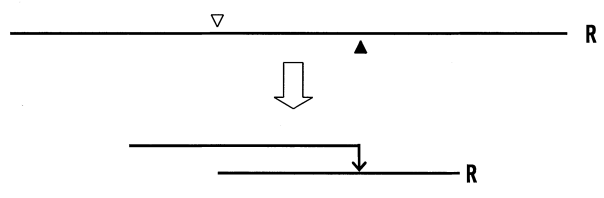

C: Cyclization reaction

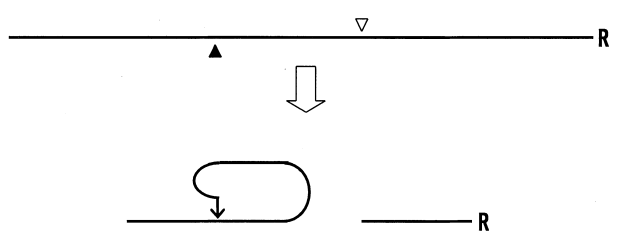

Fig. 2. Model of action of BE on amylose.

Models of intermolecular branching (A), intramolecular branching (B), and cyclization (C) reactions are shown. Solid line, $\alpha-1,4-$ glucan chain; $\mathrm{R}$, reducing end of $\alpha$-1,4-glucan chain; arrow, $\alpha-1,6-$ glucosidic linkage; $\nabla$, the $\alpha-1,4$-glucosidic linkage to be cleaved by $\mathrm{BE} ; \boldsymbol{\Delta}$, the glucosyl residue to be used as an acceptor.

応となる。

BE の触媒反応進行過程は明確になっていないが，反応 過程のいずれかの時点で, 切断される $\alpha-1,4-$ 結合（Fig. 2 における $\nabla)$ と受容体となる 6 位 $\mathrm{OH}$ 基（ム）が接近する はずである，分子間枝作り反応ならば，2本のアミロース 鎖が並んだところを想定すればよい（Fig. 2 A）が，分子 内枝作りあるいは環状化反応はどのように触媒されると考 えられるだろうか.

水溶液中において, アミロースは分子全体としてはラン ダムコイルとして挙動すると考えられている ${ }^{10)}$. したがっ て, Fig. 2 には，剛直な構造のように図示したが，実際に は単一アミロース分子の 2 点間が近接した位置をとる場合 も当然あると考える。ささに，希薄溶液中では，アミロー ス分子の分子間平均距離は, 分子自体のサイズに比べて ずっと大きいとされている ${ }^{11,12}$ 。したがって，希薄溶液中 においては，むしろ分子間枝作り反応上りも，分子内枝作 り反応，もしくは環状化反応が触媒される確率が高いかも しれない.

環状化反応と枝作り反応の比率は，基質アミロースの濃 度，および重合度（DP）に依存するとともに，BEの種類 にも依存すると考えている. BEの反応産物からは, DP 17 以下の低分子環状糖は検出されなかった て，短いグルカン鎖を優先して転移する種類の $\mathrm{BE} て ゙ は ，$ 環状化反応の触媒される確率は低くなるかもしれない. し かし，すべての BE は多かれ少なかれ環状化反応を触媒す 
るだろうと，私は考えている．

これまでに調べたところでは, 中温菌である Bacillus cereus 由来 $\mathrm{BE}^{13)}$, および超好熱性細菌 Aquifex aeolicus 由 来 $\mathrm{BE}^{14)}$ が環状化反応を触媒することを確認した。また, 北村は，馬鈴薯由来 BEをアミロースに作用させると，還 元力上昇を伴わない低分子化が起こることを報告してい る ${ }^{15,16)}$. これは, 馬鈴薯 $\mathrm{BE}$ も環状化反応を触媒すること を強く示唆するものと考える.

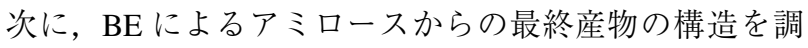
ベた. 上述のように, Fig. 2 A, B , C の 3 種の反応すべて が程度の差はあれ, 起こるはずである.さらに, どの反応 の生産物もある程度以上の直鎖部分があれば，再び BEの 作用を受けることができるはずである。そして平均鎖長が ある一定限度以下になるまで反応が続くと予想される。

まず，分子量分布の狭い $\left(\mathrm{M}_{\mathrm{w}} / \mathrm{M}_{\mathrm{n}},<1.1\right)$ 完全直鎖のア ミロースを 6 種類 $\left(M_{\mathrm{w}} 5000\right.$ から 320,000) 準備し, BEを 十分に（ $\alpha-1,6$-結合増加が停止するまで）作用させて反応 産物の構造を調べた ${ }^{13)}$. 意外なことに, どの基質を用いた 場合も主生産物の重量平均分子量はほぼ同じであった（約 60,000). 長いアミロースからはより小さな分子が主とし て生じ, 短いアミロースからはより大きな分子が主として 生じたことになる。高分子基質の場合は, 環状化反応が優 勢となり, 低分子基質の場合は, 分子間枝作り反応が優勢 となったためであろうと考えている。

\section{BE のアミロペクチンへの作用}

B. stearothermophilus の BEのアミロペクチンへの作用 を調べたところ, やはり還元力の上昇を伴わない低分子化

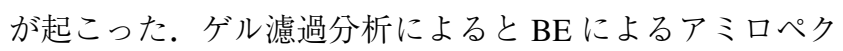
チン分解反応はある一定限度で停止していた (Fig. 3 ${ }^{17,18)}$. Table 1 に, 典型的な最終産物の構造パラメータを示す.

最終産物の単位鎖長分布を高性能陰イオン交換クロマト グラフィーを用いて調べたところ, 基質アミロペクチンと 非常によく似ていることがわかった（Fig. 4 A, B). 詳細 に比較すると（Fig. 4 C), DP 6, 7, 11 および 12 の単位 鎖と DP 22-35 の単位鎖が増加し, DP 37 以上の長い単位 鎖が減少していた。さらにDP 48 以上の単位鎖は検出で きなくなった。

次に，本生産物からの環状成分の単離を試みた。生産物 をグルコアミラーゼで完全に処理し，2.6\%の収率でエ夕

Table 1. Structural parameters of amylopectin and BE product.

\begin{tabular}{lcc}
\hline \multicolumn{1}{c}{ Parameter } & Amyopectin & $\begin{array}{c}\text { BE } \\
\text { product }\end{array}$ \\
\hline Weight-average DP & N.D.* & 900 \\
Reducing sugar (\%) & N.D. & 0.017 \\
$\alpha$-1,6 Linkage (\%) & 5.2 & 6.3 \\
Number-average chain length & 19 & 16 \\
$\beta$-Amylolysis limit (\%) & 56 & 59 \\
Exterior chain length & 13 & 11 \\
Interior chain length & 5 & 4 \\
\hline
\end{tabular}

${ }^{*}$ Not determined.
ノールで沈澱するグルカン（グルコアミラーゼ耐性グルカ ン）を得た。その構造を詳細に解析したところ, Table 2 に示すパラメータを得た。平均の分岐間鎖長 (Span length) は4.8であり, Hizukuri と Abe ${ }^{19)}$ が示したアミロペクチン の高度分岐部分の構造と大きな矛盾のないものであった.

以上の結果から, BEはアミロペクチンのクラスター構

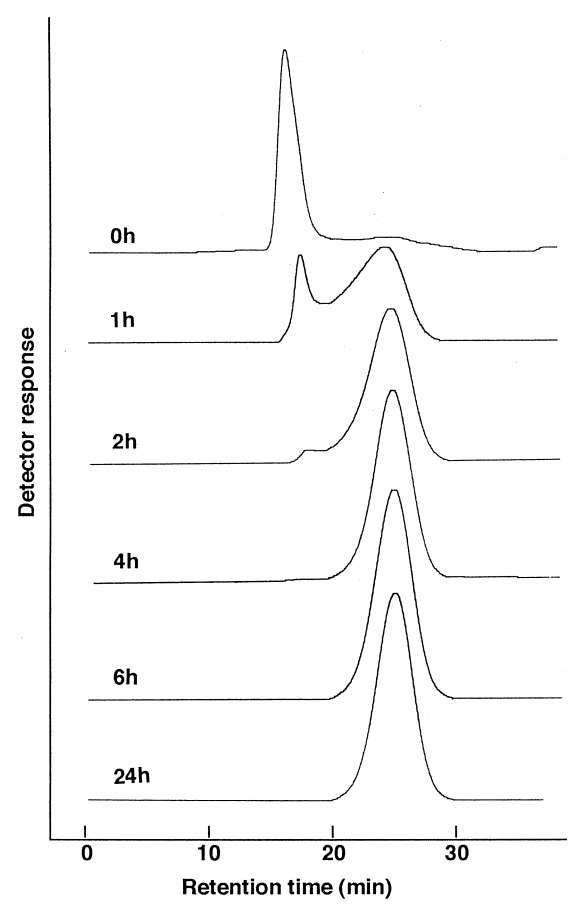

Fig. 3. Time course of action of BE on amylopectin.

Amylopectin $(0.4 \% \mathrm{w} / \mathrm{v})$ was treated with $400 \mathrm{U} / \mathrm{g}$ substrate of B. stearothermophilus BE. At intervals, the sample was removed and analyzed by gel-filtration chromatography.
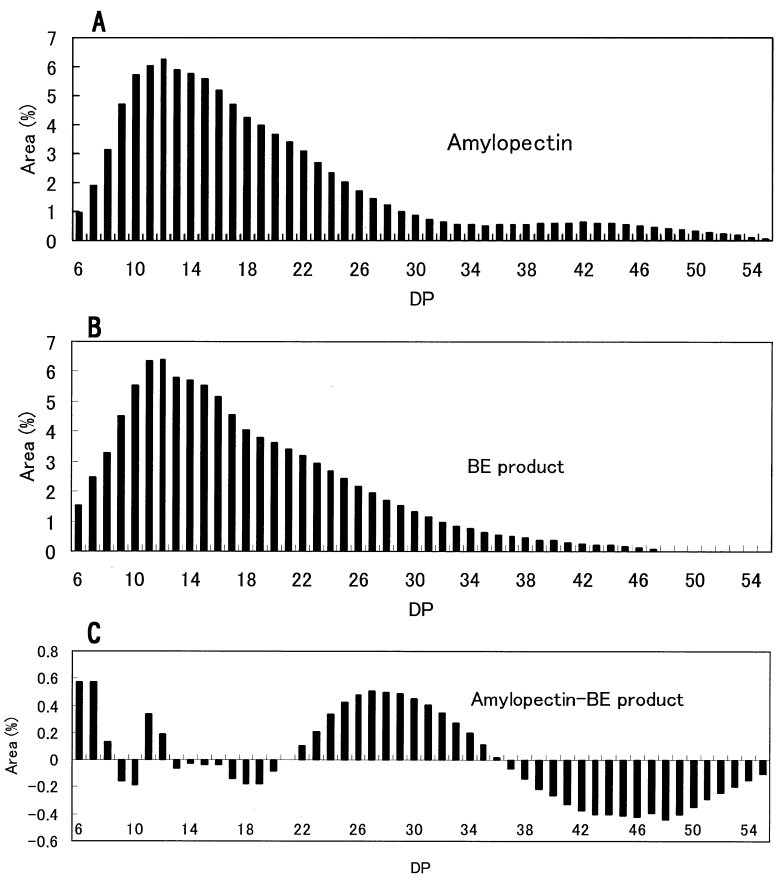

Fig. 4. Chain-length distribution of amylopectin and BE product.

The unit chains of amylopectin (A) and BE product (B) were separated by high-performance anion exchange chromatography. Panel $\mathrm{C}$ shows differential histogram between amylopectin and BE product. 
造 ${ }^{20)}$ の継ぎ目を形成する B 2 鎖以上の単位鎖に主として作 用し，これを環状化し，高度に分岐した環状糖を合成した と結論した（Fig. 5).

アミロースの環状化と異なり， BEによるアミロペクチ ンの環状化は，一般的とはいえないかもしれないと考えて いる。たとえば，Kawabata ら ${ }^{21)}$ は，Neurospora crassaの BEの作用を調べ，アミロペクチンの環状化はほとんど， あるいは全く触媒されなかったことを示している．私たち の実験でも，馬鈴薯由来 $\mathrm{BE}$ や Bacillus cereus 由来 $\mathrm{BE}$ の アミロペクチン環状化効率は, B. stearothermophilus BE と 比較して低いことが示唆されている (未発表)。一方で, Aquifex aeolicus 由来の超耐熱性 BE は, 非常に効率よくア ミロペクチン環状化反応を触媒した ${ }^{14)}$.

\section{4. クラスター デキストリン ${ }^{\mathrm{TM}}$ の製造と利用}

B. stearothermophilus BE によるアミロペクチンの環状化 は，高濃度基質を用いた場合も効率よく進行し，工業利用 に向いていることがわかった22)。この反応で得られた高度

Table 2. Structural parameters of the glucoamylase-resistant glucan.

\section{Parameter}

\begin{tabular}{lc} 
Weight-average DP & 49 \\
Number of glucosyl stubs & 5.5 \\
DP of ring structure & 43.5 \\
Number of $\alpha-1,6$ linkages in the ring structure & 3.5 \\
Number of $\alpha-1,4$ linkages in the ring structure & 40 \\
Number-average chain length & 12.4 \\
Span length & 4.8 \\
\hline
\end{tabular}

*Assuming the number-average DP was similar to weightaverage DP. ${ }^{* *}$ Average span length between $\alpha-1,6$ linkages.

\section{Amy lopect in}

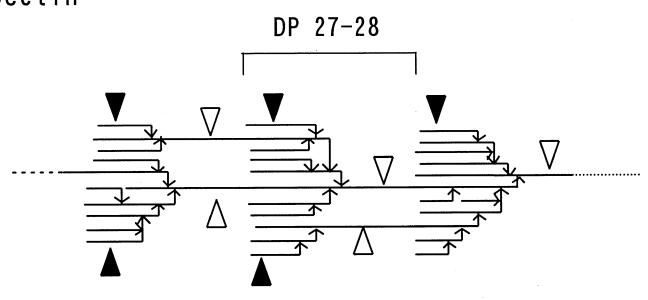

$\mathrm{BE}$

BE product

(Highly-branched cyclic dextrin)
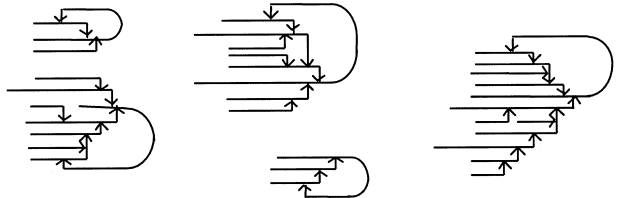

Fig. 5. Model of action of BE on amylopectin

Solid line, $\alpha$-1,4-glucan chain; arrow, $\alpha$-1,6-glucosidic linkage; $\nabla$, the $\alpha-1,4$-glucosidic linkage to be cleaved by BE; $\boldsymbol{\Lambda}$, the glucosyl residue to be used as an acceptor.
分岐環状糖質をクラスターデキストリン と舀づけ， 2002 年より販売を開始した。BEの生産性改良，クラス ターデキストリンの工業的製造方法開発は，それぞれナ ガセケムテックス(株)，日本食品化工(株)との共同研究であ る.

クラスターデキストリンは，従来のデキストリンと比 較して，分子量分布が狭い（Fig. 6），比較的長い単位鎖を 多く含む，環状部分がある（還元末端が少ない），という 構造上の特徴がある.これらの構造特性より,クラスター デ キストリンは，通常のデキストリンと比較して

(1)水に溶けやすい

(2)得られた溶液は老化しにくく安定

(3)溶液の浸透圧が低い

(4)異味異臭が少ない

(5)着色しにくい

(6)乾燥しやすく吸湿しにくい という，すぐれた特徴を有していた。また，酸味や苦味， アルコール感をマイルドにする効果，臭みを緩和する効果 をもっている ${ }^{23)}$.これは，比較的長い単位鎖に，低分子物 質を包接することができるためと考えている。これに加え て，(4)の異味異臭が少ないということから，食品本来の風 味を損なうことなく，味質を改善することが可能である.

(1)〜 (5)の特徴から，クラスターデキストリンは飲料へ の使用にも適している ${ }^{24)}$. 浸透圧が低いため，飲料に用い たときビタミンやミネラルを添加しても，適切な浸透圧に 調整しやすい。これは，胃から腸にすばやく移行する飲料 を設計する上で重要である．さらに，持久力を増強する効 果を有することもわかっている ${ }^{25)}$.

一般に，デキストリンは粉末化基剤としても沉用されて いるが，クラスターデキストリンを油脂や香料などの粉 末化基剤として用いると，従来よりも安定性の高い粉末が 得られることもわかった ${ }^{26)}$.

現在, クラスターデキストリンは，江崎グリコ(株)のス

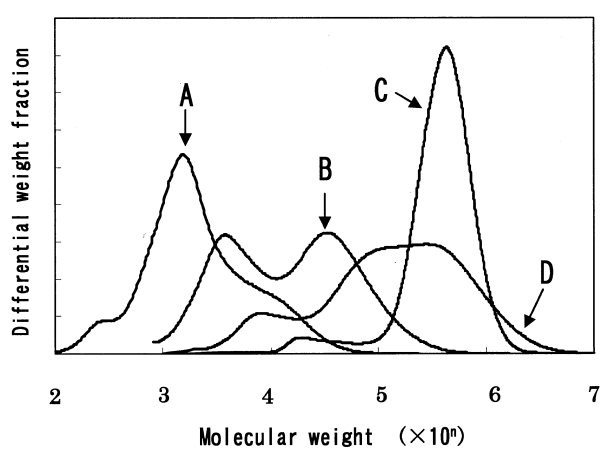

Fig. 6. Molecular weight distribution of Cluster Dextrin ${ }^{\mathrm{TM}}$ and other commercial dextrins.

Each dextrin was subjected to high-performance gel filtration chromatography with a multi-angle laser-light scattering (LS) detector and a refractive index (RI) detector. The molecular weight distribution was calculated from LS and RI signals by using software ASTRA (Wyatt Technology Co.). A, dextrin with dextrose equivalent (DE) 16; B, dextrin with DE 9; C, Cluster dextrin ${ }^{\mathrm{TM}}$; D, dextrin with DE 3. 
ポーツドリンクの主成分として採用されているほか，味質 改善効果，あるいは粉末化基剤としての効果を利用して， いくつかの製品に採用されている.

\section{5. グリコーゲンの合成}

これまでに述べてきたように，BEを単にアミロースや アミロペクチンに作用させた場合には，分子量数万〜数十 万程度のグルカンしか得られなかった。これらも高分子で

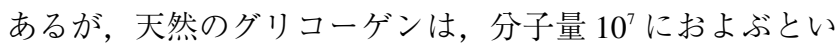
われている。そこで，天然のグリコーゲンに近い超高分子 糖質を合成したいと考えた。

グルコース-1-リン酸とプライマーを基質として $\alpha$-グル カンホスホリラーゼ（GP）を作用させるとアミロースを 合成できることはよく知られている を組み合わせてグリコーゲンを合成しようとした例も多数 報告されている（たとえば文献 27）。しかし，生産物の分 子量を詳しく調べた例はあまりない.

そこで，BEと GPを同時に作用させ， $\alpha$-グルカンを合 成した（Table 3). その分子量を光散乱法により調べたと ころ，重量平均分子量は 1000 万以上であり，天然のグリ コーゲンに匹敵するものであった。 また，平均鎖長は GP と $\mathrm{BE}$ の比を変えることにより制御可能だった ${ }^{28)}$.

\section{6. その他のグリコーゲン合成・分解系酵素について}

細菌のグリコーゲン合成・分解系酵素としては，大腸菌 由来のものが最もよく研究されている。一方で，大腸菌以 外の種由来のものについてはあまり研究されていなかっ た。

私たちは，B. stearothermophilus TRBE 14 株の BE 遺伝 子 $(g \lg B)$ の下流を調べたところ,さらにグリコーゲン 関連遺伝子が並んでいることを見出した.

そのグリコーゲン関連遺伝子群を単離し，全塩基配列を 決定したところ, 約 9400 bp の DNA 断片内に五つの遺伝 子が存在しており, $g \lg B C D A P$ とした ${ }^{29)}$. Fig. 7 に大腸菌 および B. stearothermophilus の $\mathrm{glg}$ 遺伝子群の構成を示す. B. stearothermophilus の遺伝子のうち, $g \lg C, A, P$ は, その相同性から，それぞれ ADP-グルコースピロホスホリ ラーゼ (AGP)，グリコーゲン合成酵素 $(\mathrm{GS}), \mathrm{GP}$ をコー ドすることが推定できた。

Table 3. Glycogen-like polysaccharide synthesized by cooperative action of branching enzyme and $\alpha$-glucan phosphorylase.

\begin{tabular}{ccc}
\hline $\mathrm{BE} / \mathrm{GP}^{*}$ & $\mathrm{M}_{\mathrm{w}}\left(10^{6}\right)^{* *}$ & $\begin{array}{c}\text { Number-average } \\
\text { chain length }\end{array}$ \\
\hline 62.5 & 14.0 & 38.9 \\
125 & 20.6 & 24.4 \\
250 & 19.6 & 15.7 \\
500 & 16.9 & 13.7 \\
\hline
\end{tabular}

${ }^{*}$ The ratio of activity of branching enzyme to that of $\alpha$-glucan phosphorylase. ${ }^{* *}$ Weight-average molecular weight.
一方, $g \lg D$ のコードするタンパク質 $(\mathrm{GlgD})$ は, AGP と低い相同性を有していた。実験の結果, $\mathrm{GlgC}$ タンパク 質のみでも AGP 活性があるが， $\mathrm{GlgC}$ タンパク質 2 個と, $\mathrm{GlgD}$ タンパク質 2 個からなるへテロ 4 量体型 $\mathrm{AGP}$ が構成 されることにより高い AGP 活性が発現されることがわ かった。それまで一般に植物 AGP はへテロ 4 量体型で, 細菌 AGP はホモ 4 量体型であるとされていたが，本研究 の例はそのはじめての例外となった ${ }^{30,31)}$.

その他, GS, GPについても大腸菌とB. stearothermophilus の間には，種々の差があることがわかった．詳細に

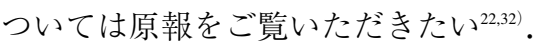

ヘテロ 4 量体型の細菌 AGP は，1997 年の私たちの発表 後，報告がない。一方，その間に多くのゲノム塩基配列が 報告されている。そこで，あらためて，GlgD類似タンパ ク質が他の生物に存在するか否か検索した。その結果, Bacillus 属細菌以外に, Streptococcus 属, Lactococcus 属, Clostridium 属, Lactobacillus 属, Deinococcus 属, Thermotoga 属等の細菌が, $\mathrm{GlgD}$ 様タンパク質をもっていること がわかった.Bacillus 属同様，これらの細菌は $\mathrm{GlgC}$ 様夕 ンパク質も同時にもっている.

これらを含む 64 種の AGP タンパク質のアミノ酸配列か ら分子系統樹を作成した（Fig. 8).この図よりAGPタン パク質は，五つのタイプに分けられることが示唆された。 仮にタイプ I-Vと名づけると，Bacillus 属や Streptococcus 属は夕イプII と III，大腸菌は夕イプVのみ，Vibrio colerae はタイプIVとVをもっていた。同じBacillus 属でも，Bacillus cereus は，タイプ而のみをもっていた。

以上のことから，へテロ 4 量体型 AGP は，グラム陽性 細菌を中心に幅広く存在すること，さらに別の夕イプの細 菌 AGP も存在する可能性があることが示唆された（未発 表).

細菌は非常に多様な環境に生息している。そして，グリ コーゲンの機能および合成タイミングも多様であることが 示唆されている。このことからも，グリコーゲン合成調節 機構，AGPの夕イプともに当然多くのバリエーションが 存在しうると考える.

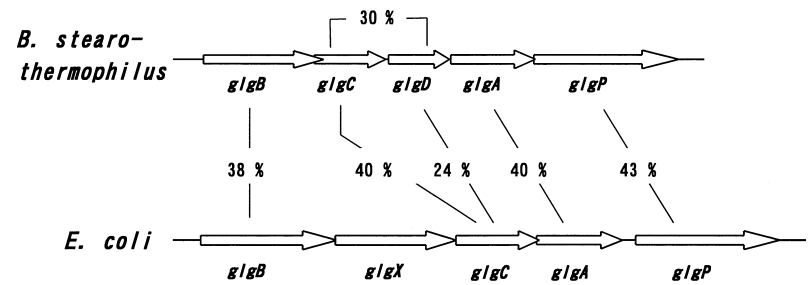

Fig. 7. Schematic representation of structures of gene clusters for glycogen biosynthesis in Escherichia coli and Bacillus stearothermophilus.

Open arrows indicate open reading frames (ORFs) on chromosomal DNA. Identities between amino acid sequences of proteins encoded by the ORFs are also shown. Encoded proteins are as follows; $g \lg B$, branching enzyme; $g \lg X$, debranching enzyme; $g \lg C$, subunit of ADP-glucose pyrophosphorylase; $g \lg D$, subunit of ADPglucose pyrophosphorylase; $g l g A$, glycogen synthase; $g l g P, \alpha$ glucan phosphorylase. 


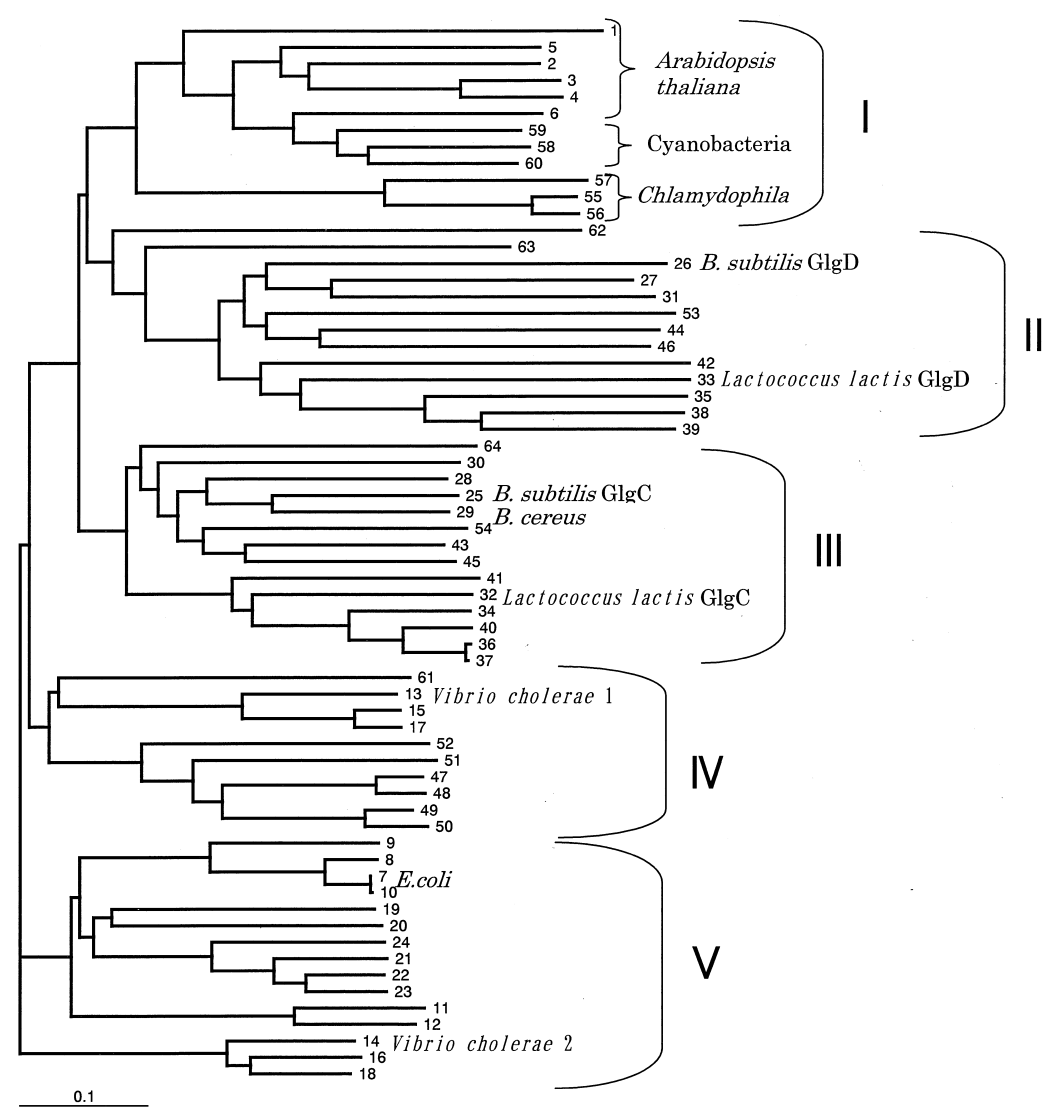

Fig. 8. Phylogenetic relationship among 64 AGP-related proteins.

The amino acid sequences used for the analysis are obtained from the web-site of Kyoto Encyclopedia of Genes and Genomes (KEGG, http://www.genome.ad.jp/kegg/), and the phylogenetic tree was constructed by using Clustal W.

The sources of AGP-related proteins are as follows; 1-6, Arabidopsis thaliana; 7, Escherichia coli K-12; 8, Salmonella typhi; 9, Yersinia pestis; 10, Shigella flexneri; 11, Haemophilus influenzae; 12, Pasteurella multocida; 13-14, Vibrio cholerae; 15-16, Vibrio vulnificus; 17-18, Vibrio parahaemolyticus; 19, Shewanella oneidensis; 20, Nitrosomonas europaea; 21, Mesorhizobium loti; 22, Sinorhizobium meliloti; 23, Agrobacterium tumefaciens; 24, Bradyrhizobium japonicum; 25-26; Bacillus subtilis; 27-28, Bacillus halodurans; 29, Bacillus cereus; 30-31, Oceanobacillus iheyensis; 32-33, Lactococcus lactis; 34-35, Streptococcus pneumoniae; 36, Streptococcus agalactiae 2603; 37-38, Streptococcus agalactiae NEM 316; 39-40, Streptococcus mutans; 41-42, Lactobacillus plantarum; 43-44, Clostridium acetobutylicum; 45-46, Clostridium perfringens; 47, Mycobacterium tuberculosis; 48, Mycobacterium leprae; 49, Corynebacterium glutamicum; 50, Corynebacterium efficiens; 51, Streptomyces coelicolor; 52, Bifidobacterium longum; 53-54, Fusobacterium nucleatum; 55, Chlamydia trachomatis; 56, Chlamydia muridarum; 57, Chlamydophila pneumoniae; 58, Synechocystis sp. PCC 6803; 59, Thermosynechococcus elongates; 60, Anabaena sp. PCC 7120; 61-62, Deinococcus radiodurans; 63-64, Thermotoga maritima.

\section{7. おわりに}

本研究では，グリコーゲン合成・分解系酵素を対象にし ていくつかの新しい知見を得ることができた。しかし，微 生物の多様性を考えると, また別の構造や, 特異性をもつ 酵素が存在することも十分あり得る. Fig. 1 にグリコーゲ ン合成系を示したが，この酵素系自体ですら全く別のパ ターンが存在するかもしれない.たとえば，藍藻において 唯一の BE 遺伝子を破壊しても少量の $\alpha-1,6$-結合が合成さ れたことが報告されている ${ }^{33)}$ 。また, 超好熱性細菌や始原 菌の一部は, そのゲノム上に GS や枝切り酵素の遺伝子は もっているにもかかわらず，BE 遺伝子をもたない。これ

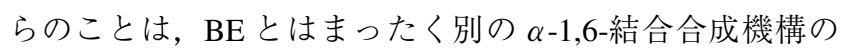
存在を示唆する。また, Neiseria 属においては, アミロス クラーゼが GS の代わりに $\alpha-1,4-$ 結合合成に使われている 可能性がある ${ }^{34)}$.これからは, さらに柔軟に自然界からの 教えを受け入れられる態度で研究に取り組みたい。

本研究遂行中, 終始ご指導ご鞭撻をいただいた, 京都大
学大学院工学研究科教授 今中忠行先生に厚くお礼申し上 げます。

また，終始あたたかいご指導をいただきました北陸先端 科学技術大学院大学教授 高木昌宏先生に感謝申し上げま す.

クラスターデキストリンの構造分析については, 鹿児 島大学名誉教授 故 檜作 進先生にご指導とご助言をいた だきました。深く感謝いたしますとともに先生のご冥福を お祈りいたします。また，大阪市立大学理学部名誉教授 南浦能至先生, 同助教授 飯塚 勝先生, 信州大学農学部 教授 北畑寿美雄先生, 大阪府立大学農学部教授 北村進一 先生に，多くのご助言，ご指導をいただきました。ここに お礼申し上げます。

クラスターデキストリンの事業化において，ご協力い ただきましたナガセケムテックス(株)の橘 佳久氏，田中悟 広氏, 鈴木裕治氏, 内田和男氏, 田中朋子氏をはじめとす る関係者の方々, 日本食品化工(株)研究所の中久喜輝夫博 士, 小川浩一博士，住吉秀幸氏，藤本佳則氏，同技術開発 
部の海野剛裕博士, 同営業第三部の中村信之博士, 山本幹 男博士をはじめとする関係者の方々に感謝します.

本研究は, 主として江崎グリコ(株)生物化学研究所で行っ たものです，終始ご指導ご鞭撻をいただいた，前取締役所 長 岡田茂孝博士に深謝いたします。また, 現所長の栗木 隆博士にお礼申し上げます。

クラスターデキストリンの事業化および用途開発の多 くは，上にあげました共同研究先のほか，江崎グリコ(株)新 規事業本部新素材担当チーム, 健康食品部, 中央研究所, 菓子開発研究所, 冷菓開発研究所, 食品開発研究所の方々 によるものです．深く感謝いたします。最後になりました が, 鷹羽武史博士, 小島岩夫氏, 柳瀬美千代氏をはじめと する生物化学研究所の先輩, 同僚諸氏に感謝いたします.

\section{文献}

1 ) D. Borovsky, E.E. Smith and W.J. Whelan: Purification and properties of potato 1,4- $\alpha$-D-glucan: 1,4- $\alpha$-D-glucan $6-\alpha-(1,4-$ $\alpha$-glucano)-transferase: Evidence against a dual catalytic function in amylose-branching enzyme. Eur. J. Biochem., 59, 615625 (1975).

2 ) D. Borovsky, E.E. Smith and W.J. Whelan: Temperaturedependence of the action of Q-enzyme and the nature of the substrate for Q-enzyme. FEBS Lett., 54, 201-205 (1975).

3 ) D. Borovsky, E.E. Smith and W.J. Whelan: On the mechanism of amylose branching by potato Q-enzyme. Eur. J. Biochem., 62, 307-312 (1976).

4 ) D. Borovsky, E.E. Smith, W.J. Whelan, D. French and S. Kikumoto: The mechanism of Q-enzyme action and its influence on the structure of amylopectin. Arch. Biochem. Biophys., 198, 627-631 (1979).

5 ) H. Takata, T. Kuriki, S. Okada, Y. Takesada, M. Iizuka, N. Minamiura and T. Imanaka: Action of neopullulanase: Neopullulanase catalyzes both hydrolysis and transglycosylation at $\alpha$ -

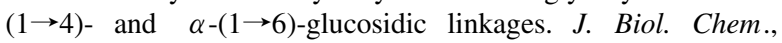
267, 18447-18452 (1992).

6 ) H. Takata, T. Takaha, T. Kuriki, S. Okada, M. Takagi and T. Imanaka: Properties and active center of the thermostable branching enzyme from Bacillus stearothermophilus. Appl. Environ. Microbiol ., 60, 3096-3104 (1994).

7 ) T. Kuriki, H.P. Guan, M. Sivak and J. Preiss: Analysis of the active center of branching enzyme II from maize endosperm. $J$. Protein Chem., 15, 305-313 (1996).

8 ) 岡田茂孝, 吉川恵温, 谷口倫夫, 北畑寿美雄: Bacillus 属 細菌の生産する枝作り酵素について。澱粉科学， 30，223230 (1983).

9 ) H. Takata, T. Takaha, S. Okada, M. Takagi and T. Imanaka: Cyclization reaction catalyzed by branching enzyme. J. Bacteriol., 178, 1600-1606 (1996).

10）北村進一：溶液中におけるアミロースのコンホメーション と物性に関する研究. 澱粉科学, 36, 303-309 (1989).

11) M.J. Miles, V.J. Morris and S.G. Ring: Gelation of amylose. Carbohydr. Res., 135, 257-269 (1985).

12) V.J. Morris: Starch gelation and retrogradation. Trends Food Sci. Technol., 1, 2-6 (1990).

13）高田洋樹, 鷹羽武史, 岡田茂孝, 高木昌宏, 今中忠行: Bacillus cereus 由来 branching enzyme による環状化反応, 農化（講演要旨）39, (1997).

14) H. Takata, K. Ohdan, T. Takaha, T. Kuriki and S. Okada: Properties of branching enzyme from hyperthermophilic bacterium, Aquifex aeolicus, and its potential for production of highly-branched cyclic dextrin. J. Appl. Glycosci., 50, 15-20 (2003).

15）北村進一：酵素合成アミロペクチンの構造と物性に関する 研究・応用糖質科学 (講演要旨), 42, 308 (1995).
16) S. Kitamura: Starch polymers, natural and synthetic. in Polymeric Materials Encyclopedia, J.C. Salamone, ed., CRC Press, Boca Raton, pp. 7915-7922 (1996).

17) H. Takata, T. Takaha, S. Okada, S. Hizukuri, M. Takagi and T. Imanaka: Structure of the cyclic glucan produced from amylopectin by Bacillus stearothermophilus branching enzyme. Carbohydr. Res., 295, 91-101 (1996).

18）高田洋樹，鷹羽武史，中村弘康，岡田茂孝，檜作 進，高 木昌宏, 今中忠行：ブランチングエンザイムによる新規環 状糖の合成. 応用糖質科学, 43, 257-264 (1996).

19) S. Hizukuri and J. Abe: A new method of enzymic analysis of amylopectin structure. in Plant Polymeric Carbohydrates; International Symposium, Berlin, Germany, July 1-3, 1992, F. Meuser, D.J. Manners and W. Seibel, eds., The Royal Society of Chemistry, Cambridge, pp. 16-25 (1993).

20) S. Hizukuri: Polymodal distribution of the chain lengths of amylopectins, and its significance. Carbohydr. Res., 147, 342347 (1986).

21) Y. Kawabata, K. Toeda, T. Takahashi, N. Shibamoto and M. Kobayashi: Preparation of highly branched starch by glycogen branching enzyme from Neurospora crassa N 2-44 and its characterization. J. Appl. Glycosci., 49, 273-279 (2002).

22) H. Takata, T. Takaha, H. Nakamura, K. Fujii, S. Okada, M. Takagi and T. Imanaka: Production and some properties of a dextrin with a narrow size distribution by cyclization reaction of branching enzyme. J. Ferment. Bioeng., 84, 119-123 (1997).

23）高田洋樹, 芳川憲司, 藤本佳則, 住吉秀幸: クラスター デキストリンのの飲料・食品への応用。食品と科学, 45 , 73-77 (2002).

24）滝井 寛：クラスターデキストリンを利用したスポーツ ドリンクの開発. 食品と開発，38，11-13 (2002).

25) H. Takii, K. Ishihara, T. Kometani, S. Okada and T. Fushiki: Enhancement of swimming endurance in mice by highly branched cyclic dextrin. Biosci. Biotechnol. Biochem., 63, 2045-2052 (1999).

26) Y. Kagami, S. Sugimura, N. Fujishima, K. Matsuda, T. Kometani and Y. Matsumura: Oxidative stability, structure, and physical characteristics of microcapsules formed by spray drying of fish oil with protein and dextrin wall materials. J. Food Sci., 68, 2248-2255 (2003).

27) D.S. Tolmasky and C.R. Krisman: The degree of branching in $(\alpha 1,4)-(\alpha 1,6)$-linked glucopolysaccharides is dependent on intrinsic properties of the branching enzymes. Eur. J. Biochem., 168, 393-397 (1987).

28) K. Fujii, H. Takata, M. Yanase, Y. Terada, K. Ohdan, T. Takaha, S. Okada and T. Kuriki: Bioengineering and Application of Novel Glucose Polymers. Biocatal. Biotransform., 21, 167-172 (2003).

29) H. Takata, T. Takaha, S. Okada, M. Takagi and T. Imanaka: Characterization of a gene cluster for glycogen biosynthesis and a heterotetrameric ADP-glucose pyrophosphorylase from Bacillus stearothermophilus. J. Bacteriol., 179, 4689-4698 (1997).

30) 高田洋樹：ADP-グルコースピロホスホリラーゼ.「澱粉科 学の事典」, 不破英次, 小巻利章, 檜作 進, 貝沼圭二編 集, 朝倉書店, 東京, pp. 80-82 (2003).

31) J. Preiss: ADPglucose pyrophosphorylase: basic science and applications in biotechnology. Biotechnol. Аnnu. Rev., 2, 259279 (1996).

32) H. Takata, T. Takaha, S. Okada, M. Takagi and T. Imanaka: Purification and characterization of $\alpha$-glucan phosphorylase from Bacillus stearothermophilus. J. Ferment. Bioeng., 85, 156161 (1998).

33) S.H. Yoo, M.H. Spalding and J. Jane: Characterization of cyanobacterial glycogen isolated from the wild type and from a mutant lacking of branching enzyme. Carbohydr. Res., 337, 2195-2203 (2002).

34) V. Buttcher, M. Quanz and L. Willmitzer: Molecular cloning, functional expression and purification of a glucan branching enzyme from Neisseria denitrificans(1). Biochim. Biophys. Acta, 1432, 406-412 (1999). 